\title{
A Time-Dependent Model of Products Liability
}

Consumers who buy manufactured goods do so with the expectation that the goods will be both fit for a particular use and capable of being used for some reasonable amount of time. Take, for example, a ladder. Most consumers expect to be able to use a new ladder for normal purposes over a considerable span of years. Although ladders will become unfit for use at varying rates of speed, as the years pass even the most durable ladder inevitably deteriorates. When a worn-out rung finally gives way, who should bear the cost of the resulting injury-the manufacturer or the consumer?

This is only one example of the problem that product age poses for a products liability tort system. In particular, it shows that the increasing risk of accidents as products become more dangerous with use and age bears on the selection of a liability rule. Although manufacturers may be held to very strict standards when they offer products to the public, it is clear that they should not be required to offer only products that have an infinite useful life. The fact that products age, then, raises the question of how to allocate, as between the manufacturer and the consumer, the costs of injuries caused by products that simply wear out due to the passage of time. ${ }^{1}$

This comment uses economic analysis to examine how the factor of product age bears upon the selection of a standard of manufacturer liability. It attempts to determine the optimal standard of liability over time from the perspective of social cost minimization. ${ }^{2}$ Along the way it explains how expressly incorporating prod-

1 In this comment, the term "manufacturer" identifies anyone who participates in the distribution of a product to the public. This includes any wholesaler and retailer, along with the manufacturer itself, since liability for defective products can be found against any link in the chain of manufacture or distribution. See W. KEETON, D. DoBRs, R. KeETon \& D. OWen, Prosser and Keeton on the LaW of Torts § 100, at 703-07 (5th ed. 1984) [hereinafter cited as Prosser \& KeETon]. Also, the term "consumer" is not synonymous with "purchaser," but identifies any user of a product. For instance, an employee who is injured in a product-related accident would be classified as a consumer even though the employer owns the product.

2 This comment approaches the problem of defining a standard of liability from an economic perspective, thus with one value at the forefront-the minimization of the social costs of accidents. See infra notes 16-23 and accompanying text (describing the basic eco- 
uct age in the determination of the optimal standard of liability for product-wear injuries improves upon the established economic model of tort law.

Part I briefly examines how courts have dealt with the problem of product age. Part II sets out a time-dependent economic model of tort law. This model is used to evaluate various liability rules by measuring the incentives they provide for people to behave in ways that minimize the social cost of accidents. The model suggests that when products reach a certain age the standard of manufacturer liability should shift from a rule of strict liability with a defense of contributory negligence to a negligence rule. Part III examines current judicial practice in light of the model. The comment shows that the model's conclusions are largely reflected in current products liability law. A concluding discussion defends the model's conclusions against possible criticisms raised by the problem of administrative costs, but notes that the conclusions might differ if more accurate information were available concerning the administrative costs imposed by the various standards of tort liability.

\section{Time AND the Courts}

For many decades courts refused to find manufacturers liable for injuries that could be traced ultimately to product wear. This approach fit well when the prevailing tort law standard was one of negligence: under this standard, manufacturers were liable only if the injured consumer could demonstrate that the product was negligently made and hence "imminently dangerous." Because product wear cannot be entirely prevented even by due care in the manufacturing process, the manufacturer was protected from liability as long as the product was reasonably durable. Thus, the negligence rule placed the cost of wear-related accidents on the consumer.

This approach was applied in the 1941 case, Auld v. Sears,

nomic model). While a consideration of the social costs of accidents is certainly important to the selection of a liability rule, other values-compensation of victims, for example-are also relevant. The analysis that follows does not take into account such non-economic values, and thus should be read in light of its perspective.

${ }^{3}$ See, e.g., MacPherson v. Buick Motor Co., 217 N.Y. 382, 389, 111 N.E. 1050, 1053 (1916). Under the law as expressed in MacPherson, a manufacturer's liability to remote users of a product was limited. The manufacturer must have had knowledge of probable (not merely possible) danger and must have foreseen use of the product by people other than the purchaser. Id. at 389-91, 111 N.E. at 1053-54. 
Roebuck \& Co.4 Auld was injured by a washing machine sold to him by Sears. At trial Sears established that the accident occurred because a pin which held the machine's wringer in place wore out due to the passage of time. The court held that since "[c]ommon sense and every day experience teaches us that machinery will wear out," Sears had no duty to provide a washing machine that would last forever. ${ }^{5}$ Thus it could not be liable for an accident caused by wear. Instead, any duty to repair or keep the machine in good order rested solely upon the plaintiffs. ${ }^{6}$

The principle expressed in Auld was put in jeopardy by the advent of strict products liability. Beginning in the $1960 \mathrm{~s}$, courts began to discard the requirement that injured consumers prove negligence in the manufacture of defective products. ${ }^{7}$ Instead, in most jurisdictions products liability actions are now governed by a standard like that expressed in section $402 \mathrm{~A}$ of the Restatement (Second) of Torts:

4261 A.D. 918, 25 N.Y.S.2d 491 (1941), aff'd mem., 288 N.Y. 515, 41 N.E.2d 927 (1942).

s Id. at 918-19, 25 N.Y.S.2d at 493; see also Hanna v. Fletcher, 231 F.2d 469, 472-73 (D.C. Cir.) (en banc) (Prettyman, J., dissenting) (weather and wear on staircase railing just as likely to have caused it to collapse as negligent repair), cert. denied, 351 U.S. 989 (1956); Campo v. Scofield, 301 N.Y. 468, 472, 95 N.E.2d 802, 804 (1950).

- 261 A.D. at 918, 25 N.Y.S.2d at 493; cf. Nelson v. Swedish Hosp., 241 Minn. 551, 557, 64 N.W.2d 38, 43 (1954) (imposing the burden of repairing an X-ray machine on hospital because the machine "was part of the hospital's permanent equipment. The duty rested upon them to inspect and maintain it in a safe operating condition.").

? In Henningsen v. Bloomfield Motors Inc., 32 N.J. 358, 161 A.2d 69 (1960), an implied warranty of safety was extended to product users other than the purchaser. The scope of the warranty approach to liability was, however, limited by standard contract principles that required the victim to give reasonable notice of his injury, see, e.g., UNIFORM SALES ACT $\S 49$ (1906); U.C.C. § 2-607(3) (1977), and allowed the manufacturer to expressly disclaim all warranties, see, e.g., UNIFORM SALES Act \& 71 (1906); U.C.C. \$ 2-316 (1977). Although courts managed to avoid these restrictions by judicial sleight of hand, it was far easier for them to abandon the warranty approach entirely and adopt a strict liability standard. See Prosser, The Assault Upon the Citadel (Strict Liability to the Consumer), 69 YALE L.J. 1099, 112734 (1960).

Today most jurisdictions follow the "strict liability for defect" standard first announced in Greenman v. Yuba Power Prods., 59 Cal. 2d 57, 27 Cal. Rptr. 697, 377 P.2d 897 (1963), and later adopted by the ReSTATEMENT (SECOND) of ToRTS $\S 402 \mathrm{~A}$ (1965). That standard of liability requires that in order to make out a cause of action against a manufacturer the plaintiff must produce evidence that:

(1) claimant's injury or illness was attributable to a dangerous condition of a product identified as being one that was supplied by the target defendant, either as a manufacturer or some other seller or supplier in the marketing chain; (2) the product was defectively dangerous at the time of the damaging event out of which the claimant's injury or illness arose; (3) the defective condition was a cause of the damaging event; (4) the defective condition was in existence at the time possession was surrendered by the defendant; and (5) the defective condition was a proximate or legal cause of the damaging event.

Prosser \& KeEton, supra note $1, \S 103$, at 713. 
(1) One who sells any product in a defective condition unreasonably dangerous to the user or consumer or to his property is subject to liability for physical harm thereby caused to the ultimate user or consumer, or to his property, if (a) the seller is engaged in the business of selling such a product, and (b) it is expected to and does reach the user or consumer without substantial change in the condition in which it is sold.

(2) The rule stated in Subsection (1) applies although (a) the seller has exercised all possible care in the preparation and sale of his product, and (b) the user or consumer has not bought the product from or entered into any contractual relationship with the seller. ${ }^{8}$

Even though manufacturer liability for wear-related accidents might serve the same policies of compensation and cost spreading that justify strict liability, ${ }^{\theta}$ courts continue to deny recovery for injuries caused by product wear. For example, the Auld principle was applied in a case decided three decades later, Kaczmarek $v$. Mesta Machine Co. ${ }^{10}$ Kaczmarek's decedent was killed at work by a malfunctioning pickling machine. The court relieved the manufacturer of liability for a broken component part, a chain, because the chain had been in use for two years before the accident. According to the court, the defendant had no duty "to furnish a chain that would not wear out," or to "guard against any injury which results from wear and deterioration of parts."11 The court echoed the reasoning of Auld: the decedent's employer, and not the manufacturer, was obligated to make "frequent, if not periodic inspections and replacements of the worn parts as soon as they are detected."12

8 Restatement (Second) of Torts § 402A (1965). Since liability turns on proof of defect, manufacturer liability is not absolute. But see infra note 42 and accompanying text.

- Courts have accepted strict products liability for three reasons: it spreads the costs of accidents by imposing strict liability on manufacturers, who can pass the costs on to consumers in the form of higher prices; it encourages accident prevention by forcing manufacturers to insure the risks imposed by their products; and it avoids burdening plaintiffs with a need to prove manufacturer negligence, which is extremely difficult as a result of the institutional and economic limits of litigation. See Prosser \& KeEton, supra note 1, § 98, at 692-93 \& nn.3-5.

10463 F.2d 675 (3d Cir. 1972).

11 Id. at 678.

12 Id.; accord Auld, 261 A.D. at 918, 25 N.Y.S.2d at 493; see also Mitchell v. Ford Motor Co., 533 F.2d 19, 21 (1st Cir.) ("The law is that a manufacturer does not have to anticipate that maintenance will be neglected."), cert. denied, 429 U.S. 871 (1976); McBride v. Ford Motor Co., 105 Idaho 753, 762, 673 P.2d 55, 64 (1983) ("A manufacturer is entitled to assume that its product will be properly maintained."); Ulrich v. Kasco Abrasives Co., 532 S.W.2d 197, 201 (Ky. 1976) ("[The manufacturer] is entitled . . . to rely on the owner of the 
The effective result of cases like Kaczmarek is to vary the standard of manufacturer liability over the course of a product's lifetime. When a new product is shown to be the cause of an accident, courts generally presume the existence of a defect; consequently, manufacturer liability is determined essentially by a rule of strict liability. ${ }^{13}$ When an older product is shown to be the cause of an accident, courts generally presume that the product simply wore out unless the plaintiff can demonstrate manufacturer negligence; consequently, manufacturer liability is determined by a negligence standard. ${ }^{14}$ The economic model of tort liability developed in the next section demonstrates that this shift in the standards of liability provides the proper economic incentives for product use.

\section{A Time-Dependent Model of Tort Law}

The economic model of tort liability seeks to evaluate the costs of accidents to society. ${ }^{15}$ It recognizes as a first principle that the parties involved in an accident-injurer and victim-seldom have an opportunity before the accident to negotiate about how to allocate the costs of the accident or its prevention. Legal rules at-

machine to assume responsibility for keeping it in safe working order.").

${ }^{13}$ See infra note 42 (citing cases and authorities); Schwartz, New Products, Old Products, Evolving Retroactive Law, 58 N.Y.U. L. REv. 796, 828-36 (1983) (discussing the "malfunction theory," whereby original defect is presumed if the injury occurs shortly after purchase). The manufacturer can avoid liability by demonstrating that the accident resulted from product wear or the consumer's failure to properly maintain the product.

${ }^{14}$ See, e.g., Mitchell v. Ford Motor Co., 533 F.2d 19, 20 (1st Cir.) ("a manufacturer is not under a duty to supply materials that will not wear out"), cert. denied, 429 U.S. 871 (1976); Siruta v. Hesston Corp., 232 Kan. 654, 684, 659 P.2d 799, 818 (1983) (Schroeder, C.J., dissenting) ("The rule is that a manufacturer does not have an obligation to manufacture a product that will not wear out."); Barich v. Ottenstror, 170 Mont. 38, 44, 550 P.2d 395, 398 (1976) ("A manufacturer or seller is not required . . . to produce or sell a product that will never wear out."); see also Savage v. Jacobsen Mfg. Co., 396 So. 2d 731, 733 (Fla. Dist. Ct. App. 1981) ("to hold otherwise would be tantamount to suggesting that a manufacturer is an insurer of his products"); Foster v. Marshall, 341 So. 2d 1354, 1361 (La. Ct. App.) (a manufacturer "cannot be expected to design products with component parts which will never wear out"), cert. denied, 343 So. 2d 1067 (La. 1977); Jakubowksi v. Minnesota Mining \& Mfg., 42 N.J. 177, 185, 199 A.2d 826, 831 (1964) ("[T]here is no duty on the part of a manufacturer to furnish tools which will not wear out."); Courtois v. General Motors Corp., 37 N.J. 525, 543, 182 A.2d 545, 554 (1962) (no duty on manufacturer since the "knowledge is universal that manufactured articles which depend upon moving parts . . . will eventually suffer fatigue and wear out"); Gomez v. E.W. Bliss Co., 27 Misc. 2d 649, 651, 211 N.Y.S.2d 246, 248 (Sup. Ct. 1961) ("Clearly, there is no duty on the part of the manufacturer to furnish a machine that will not wear out.").

${ }^{16}$ The basic model was first developed in Brown, Toward an Economic Theory of Liability, 2 J. LEGAL STUD. 323 (1973). It has since been the subject of further scholarly development. See, e.g., Landes \& Posner, The Positive Economic Theory of Tort Law, 15 GA. L. REv. 851 (1981); Shavell, Strict Liability Versus Negligence, 9 J. Legal Stud. 1 (1980). 
tempt to fill this gap by providing standards of behavior that inform the parties before the accident about how its costs will be allocated afterwards. The normative economic theory of tort law tries to prescribe legal rules that minimize the total social cost of the accident. Social cost includes the costs of preventing the injury and the expected costs of sustaining the injury along with the cost of administering the legal rule itself. This section sets forth the traditional economic model of accidents, then suggests how it ought to be altered to account for product aging.

\section{A. Developing the Model}

The traditional economic model defines the social cost of an accident in the following terms: ${ }^{16}$

$$
\begin{aligned}
C= & \text { the total social cost of the potential acci- } \\
\text { dent. } & \text { the amount of damage if the accident } \\
\text { occurs. } & \text { the number of units of care taken by the } \\
\text { injurer. } & \text { the cost of one unit of care for the injurer. } \\
W_{x}= & \text { victim. } \\
Y= & \text { the cost of one unit of care for the victim. } \\
W_{y}= & \text { the probability that an accident is avoided } \\
& \text { given that the injurer and victim exercise a } \\
& \text { certain level of care. } \\
P(X, Y)= & \text { the change in the probability that an acci- } \\
\text { dent is avoided if the injurer increases his } & \text { care level by one unit. } \\
P_{x}(X, Y)= & \text { the change in the probability that an acci- } \\
\text { dent is avoided if the victim increases his } & \text { care level by one unit. } \\
P_{y}(X, Y)= & \text { the cost of administering the liability rule. }
\end{aligned}
$$

Using these terms, the total social cost of a potential accident can be written as follows:

$$
C=W_{x} X+W_{y} Y+(1-P(X, Y)) A+K_{L}
$$

An accident's social cost thus has four components: the cost of 
avoidance to the injurer; the cost of avoidance to the victim; ${ }^{17}$ the total expected cost of the accident itself, given the subsequent conduct of both the injurer and the victim; and the cost of administering a liability rule that governs the distribution of these costs. ${ }^{18}$

From this equation, it follows that out of all the possible levels of care that the injurer and victim could exercise, there is some combination where the social cost of the accident $(C)$ is minimized. These levels of care, expressed as $X^{*}$ and $Y^{*}$, represent the socially optimal levels of care for the injurer and victim, respectively. These optimal levels of care can also be expressed in terms of the marginal benefits of each party's expenditures on care. At these optimal levels, each party has increased its expenditures on care until the cost of an additional unit of care equals the reduction in expected accident costs. ${ }^{19}$ In algebraic terms,

$$
W_{x}=P_{x}(X, Y) A
$$

and

$$
W_{y}=P_{y}(X, Y) A .^{20}
$$

While this model works well in standard physical injury cases-for instance, where an injurer accidentally strikes a victim-it omits one element that is necessary to explain injuries

17 The model developed in this comment restricts itself to consideration of those accidents where only two parties are involved. Only injurer and victim behavior are assumed to bear on the social costs of accidents.

18 Commentators using the economic model have assumed that administrative costs of different liability rules are equal, and thus have omitted any term for administrative costs. See Brown, supra note 15, at 325-26; Landes \& Posner, supra note 15, at 869. But see infra note 49 and accompanying text. The initial discussion of the model presented here, which does contain such a term $\left(K_{L}\right)$, will also assume that administrative costs of all liability rules are equal. But it should be noted that the model's solutions are only definite as long as administrative costs do not vary depending on the liability rule. If this assumption is incorrect, other solutions become possible. For a discussion of how the administrative costs problem may affect the analysis under the model, see infra notes 44-61 and accompanying text.

10 This expression is often referred to as the "incremental Hand formula," after Judge Learned Hand's decision in United States v. Carrol Towing Corp., 159 F.2d 169, 173 (2d Cir. 1947). Under the incremental Hand formula, a party is deemed to be negligent if the cost of an additional unit of care is less than the reduction in expected accident costs. See Brown, supra note 15 , at $332-35$.

${ }^{20}$ In order for these results to make sense, two mathematical conditions must hold. First, the functions $P_{x}$ and $P_{y}$ must both be positively defined over the relevant domains. Second, the first derivative of the functions must be decreasing. In layman's terms this means two things. First, the probability of avoiding an accident should increase as the amount of care exercised by an injurer or victim increases. Second, each additional unit of care exercised should produce a smaller increase in the likelihood of avoiding an accident than that produced by each unit of care which has gone before. Further increases in care therefore give a dimininishing return in protection. Intuitively, such a probability function seems sensible. 
caused by products. In the standard physical injury case, the probability that an accident can be avoided depends solely on the level of care taken by the injurer and the victim. When the accident involves a durable good, however, the probability of an accident occurring also depends upon the passage of time. Thus the minimization of the social cost of product-related accidents requires attention not only to the amount of care that should be exercised, but to the age of the product as well.

To make the model accurate for product-related accidents, it must take account of the time element. Such a time-dependent model can be written as follows:

$$
C=W_{x} X+W_{y} Y+(1-P(X, Y, T)) A+K_{L}
$$

with $T$ representing the age of the product. In this model, because the social cost of an accident depends upon the age of the product, ${ }^{21}$ the optimal injurer and victim care levels $\left(X^{*}\right.$ and $\left.Y^{*}\right)$ also become dependent on the product's age. The aggregate social cost is thus minimized when

$$
W_{x}=P_{x}(X, Y, T) A
$$

and

$$
W_{y}=P_{y}(X, Y, T) A .
$$

\section{B. Implications of the Model}

The economic model predicts that two liability rules are optimal. ${ }^{22}$ The first is a rule of strict liability with a defense of contributory negligence. Under such a rule, the victim has an incentive to exercise $Y^{*}$ in care. Any lesser expenditure risks accidents for

21 The new equations explicitly depend only upon the age of the product (T). The increased probability of an accident depends, of course, upon the deterioration of the product, which is a function both of its age and the intensity of its use. While the variable $T$ only reflects the first of these components, the latter factor is reflected in the change in the victim's optimal amount of care $\left(Y^{*}\right)$. The consumer must realize that the probability of an accident occurring increases with every use of a product, thus requiring the consumer to exercise incrementally greater care with each use.

${ }^{22}$ Properly speaking, the model predicts that three rules of liability will lead to socially optimal levels of care: strict liability with a defense of contributory negligence, simple negligence with no defense, and negligence with a defense of contributory negligence. See Brown, supra note 15 , at $338-43$. The first two rules are analytically symmetrical in that under the former, the injurer bears the costs of the accident unless the victim is negligent; under the latter, the victim bears the costs unless the injurer is negligent. Because the third rule yields essentially the same results as does the second rule under the model, it is not considered separately in the discussion. Also, it should be noted that comparative negligence is not an efficient liability rule under the model. 
which the victim could not recover at all because of contributory negligence. Given that the victim can be expected to exercise $Y^{*}$ in care, the injurer will be liable for all injuries that occur. Thus, the injurer has a strong incentive to exercise $X^{*}$ in care in order to minimize the sum of the injurer's expected liability and costs of taking care. ${ }^{23}$

A simple negligence rule produces the same result. Here the injurer has an incentive to exercise $X^{*}$ in care. Any lower level of care risks accidents for which the injurer would be liable because it was negligent. Given that the injurer can be expected to exercise $X^{*}$ in care, the victim will bear the costs of all injuries that occur. Thus, the victim has an incentive to exercise $Y^{*}$ in care, which will minimize the sum of the victim's expected accident costs and his costs of taking care.

However, a closer look at the concept of care shows that the strict liability and negligence rules do not necessarily achieve identical results. The level of care taken by a party can be separated into two distinct components. A party can exercise caution in performing an activity ${ }^{24}$-for instance, by looking both ways before crossing a street. Or a party can adjust the frequency of engaging in an activity-by crossing one street per day instead of a hundred. ${ }^{25}$

${ }^{23}$ In mathematical terms, the result flows from the private cost schedules faced by both the injurer and the victim. Under a strict liability standard, the injurer's cost schedule is:

and

$C_{x}=W_{x} X+(1-P(X, Y, T)) A$, for $Y=Y^{*}$

$C_{x}=W_{x} X$, for $Y<Y^{*}$

Assuming that the victim will be non-negligent, the injurer's private cost-minimization condition will be identical to the social cost-minimization condition:

$W_{x}=P_{x}\left(X, Y^{*}, T\right)$.

Consequently, the injurer will behave in the optimal fashion.

A consideration of the victim's private cost schedule shows why the injurer must assume that the victim will be non-negligent:

and

$C_{y}=W_{y} Y+(1-P(X, Y, T)) A$, for $Y<Y^{*}$

$C_{y}=W_{y} Y$, for $Y>Y^{*}$.

For $Y^{\prime}<Y^{*}$ the injurer's private costs decrease, regardless of the injurer's choice, since the injurer has no incentive to exercise greater care than $X^{*}$. For $Y>Y^{*}$ the victim's private costs increase. Thus, the victim's minimum cost occurs at $Y=Y^{*}$.

For a detailed mathematical proof of these propositions, see Brown, supra note 15, at 343.

24 Much of the literature refers to this portion of the care input as the "care level" component. See, e.g., Shavell, supra note 15, at 2. Because this terminology confuses care levels and care inputs, this comment substitutes the term "caution level."

${ }^{25}$ In the products liability context, the concepts of "activity level" and "caution level" need to be defined in slightly more detail. For the manufacturer the concept of activity level 
This distinction affects the predictions of the model in at least two ways. First, adjustments to caution level and adjustments to activity level will involve different costs. For example, getting into the habit of looking both ways before crossing the street will be less burdensome to a person than refraining entirely from crossing streets. Second, different kinds of care will be more or less effective in preventing an accident. Not crossing streets may reduce the chance of an accident to zero; looking both ways will not. Thus, the caution-activity distinction has implications for the costs of taking care $\left(W_{x}\right.$ and $\left.W_{y}\right)$ and for the change in probability of an accident that results from those expenditures $\left(P_{x}(X, Y, T)\right.$ and $\left.P_{y}(X, Y, T)\right)$. This, in turn, has two consequences for the choice of a liability rule, one that is recognized by both the traditional model and the time-dependent model, and another that is unique to the time-dependent model.

1. Institutional Ability of Courts. In order to properly apply either optimal liability rule, courts must be able to measure the activity levels and caution levels of the parties. If courts systematically err in applying the rule, parties will not have the incentives to expend the optimal amounts $\left(X^{*}\right.$ and $\left.Y^{*}\right)$ on care. ${ }^{26}$ In practice, however, the courts' institutional ability to measure and then determine the relative allocation of a party's expenditures on activity and caution forms of care is limited. On the one hand, courts are capable of gauging the parties' expenditures on levels of caution because courts usually have all the evidence regarding a specific accident before them. But the evaluation of activity levels is often more difficult; it may require evidence about a party's conduct over a long period of time, and that calls for a proceeding of enormous complexity. ${ }^{27}$ The courts' institutional limitations thus inhibit their ability to evaluate each party's activity level in order to determine whether that party was negligent. This means that a theo-

is straightforward; it is reflected in the number of products sold in a given period of time-for example, one million ladders per year. The consumer's activity level also can easily be defined as the number of times the consumer uses the product in a fixed period of time. "Caution level," on the other hand, comprises the entire range of elements discussed in standard negligence cases. It encompasses the specific precautions employed by the manufacturer in production-observing industry standards, for instance-and the precautions taken by the consumer in using the product-for example, following the manufacturer's instructions. See Landes \& Posner, supra note 15, at 871, 875-76.

${ }^{28}$ The earlier literature failed to recognize this complication, see, e.g., Brown, supra note 15, but later publications identified it and demonstrated its consequences for selection of a liability rule, see Landes \& Posner, supra note 15, at 871, 875-76; Shavell, supra note 15, passim.

${ }^{27}$ See Landes \& Posner, supra note 15, at 875-76. 
retically optimal liability rule may not necessarily yield optimal results in practice. ${ }^{28}$

It is this practical problem-the costly nature of inquiries about activity levels - that provides a basis for preferring either a rule of strict liability or a negligence rule in particular categories of cases. ${ }^{29}$ As the model shows, both of these rules lead to a minimization of the social cost of product-related accidents in an ideal world. In practice, however, because of the difficulty of the inquiry into activity levels, the "optimal" rule would seem to be the one which minimizes the need for this inquiry in particular cases. This suggests that in those categories of cases where it is obvious that one party's activity level is an important component of the optimal care mix, it makes sense to presume that party to be liable. Thus the challenge is to determine which party's activity level is more important to control-from there the liability rule which leads to the smaller social cost can be implemented.

Applying this insight shows that a rule of strict liability with a defense of contributory negligence should be favored when the activity level is an important component of the injurer's optimal input, but not of the victim's input. The paradigm activities for which a rule of strict liability is appropriate are abnormally dangerous activities-blasting, for example. ${ }^{30}$ The simplest method of reducing the damage to nearby structures that inevitably results from blasting is for those who engage in that business to engage in less of it. There is little or nothing a victim can do to protect himself from injury. By employing a strict liability rule the court will avoid engaging in an expensive inquiry into the injurer's activity level. Instead, the court need only focus upon the victim's caution level. Because the injurer will bear the full cost of an accident as long as the victim is not negligent, the injurer will have incentive to behave in an optimal fashion, and will do so by altering his activity level, his caution level, or some combination of both. ${ }^{31}$

In contrast, in circumstances where activity level is a more important component of the victim's input than of the injurer's, the

28 See Shavell, supra note 15, at 2-4.

29 For an examination of the traditional tort law areas of strict liability in light of the distinction between activity level and caution level, see Landes \& Posner, supra note 15, at 904-16.

so See Restatement (Second) of Torts § § 519, 520 (1977).

s1 It should be emphasized that a true strict liability rule is not identical to the standard set out in section $402 \mathrm{~A}$ of the Restatement. The latter requires proof of defect while the former does not. See infra notes 40-43 and accompanying text (discussing this difference and how it is applied by courts). 
activity level-caution level distinction demonstrates that a negligence rule should be applied. Under a negligence rule the court can limit itself to inquiring whether the injurer acted negligently. If the injurer was not negligent, the victim will bear the full cost of the accident. The victim will have an incentive to reduce these expected losses as far as possible by appropriately adjusting both his activity level and his caution level. Thus, returning to the case of a purchaser of a ladder, the purchaser will increase his care input under a negligence rule both by exercising greater caution-checking the ladder more throughly-and by reducing his activity level-using the ladder less frequently. ${ }^{32}$

2. Distinguishing New and Worn Products. A liability rule must also account for the changes in the optimal levels of activity and caution forms of care that occur as the product ages; in this regard the time-dependent model proposed by this comment differs from its static-model predecessor. The newer model recognizes that the optimal care inputs of the injurer and the victim $\left(X^{*}\right.$ and $Y^{*}$ ) vary as the product becomes older. As these optimal inputs change over time, the mix of activity and caution levels which constitute those optimal inputs will also vary. This change in activity and caution levels indicates that one liability rule may be appropriate when the product is new, and another when the product is older. Thus, unlike the static model, the time-dependent model recognizes that a shift in liability rules may be appropriate as time passes.

A good way to apply this insight of the time-dependent model is to look first at which liability rule is optimal for new products. This inquiry focuses on whether it is more important to control the manufacturer's activity level or the consumer's activity level during the time immediately following manufacture. For aging products, however, applying the model requires a two-step analysis of the effects of the passage of time: (1) how the increased risk of accident over time affects the optimal injurer and victim inputs $\left(X^{*}\right.$ and $Y^{*}$ ); and (2) if the optimal inputs are altered, how that change is likely to be apportioned between caution level and activity level. ${ }^{33}$

${ }^{32}$ Under the model, this point is strictly true for a simple negligence rule. If the negligence rule allows a defense of contributory negligence, the analysis differs slightly though the same result follows.

${ }^{33}$ A possible third step in the inquiry would be to determine whether at a particular point in time the relative changes in the parties' optimal activity and caution levels are sufficient to require a shift in the liability rule. This inquiry is necessary to determine precisely when the shift should take place. See infra notes 37-39 and accompanying text (dis- 
For new products, it is reasonable to assume that it is more important to control the manufacturer's activity level than it is to control the consumer's. The overwhelming majority of new products can be used repeatedly with relatively little risk of accident, which indicates that a reduction in the victim's activity level would be an inefficient way to reduce the probability of new product accidents. In contrast, no matter how much caution a manufacturer exercises, some defects and accidents are inevitable. It is thus intuitive to attribute the majority of accidents that occur early in a product's life to defective manufacture rather than lack of consumer care. These accidents can be avoided only by reducing the manufacturer's activity level-the number of products manufactured and sold. And this can be accomplished only if strict liability with a defense of contributory negligence is the legal rule. ${ }^{34}$

The passage of time alters this analysis. Because the probability of an accident occurring rises with a product's age, the parties should use increasing amounts of care over the product's life. In terms of the time-dependent model, this result can be expressed as follows:

$$
\left(1-P\left(X, Y, T_{2}\right)\right)>\left(1-P\left(X, Y, T_{1}\right)\right), \text { for } T_{2}>T_{1}
$$

which implies that

$$
X^{*}\left(T_{2}\right)>X^{*}\left(T_{1}\right)
$$

and

$$
Y^{*}\left(T_{2}\right)>Y^{*}\left(T_{1}\right) \cdot{ }^{35}
$$

In addition to causing a change in the optimal care inputs of both the manufacturer and the consumer, the aging of a product

cussing the timing of the shift).

${ }^{34}$ A negligence rule might be optimal if the class of injured consumers could be restricted to product purchasers. In such a case, the real price of the good to the purchaser would be the manufacturer's price plus an amount equal to the purchaser's expected accident costs. Knowing this, consumers would base their purchase decisions on prices that reflect the full cost of the product, thus leading to a reduction in the number of products sold. But, because in real life third parties are also accident victims, and the expected costs of third-party accidents are not reflected in the price the purchaser pays to use the product, a negligence rule leads purchasers to base purchase decisions upon a price that is too low.

${ }^{33}$ This result-that an increase in the probability of an accident occurring means an increase in optimal care-input levels-makes mathematical as well as intuitive sense. Where the probability of avoiding an accident is lower, the incremental gains (in reduced expected accident costs) from an additional unit of care are greater:

$P_{x}\left(X, Y, T_{2}\right)>P_{x}\left(X, Y, T_{1}\right)$.

Graphically, this means the decreasing function $P_{x} A$ shifts to the right as time passes and intersects the line $W_{x}=k$ (where $k$ is a constant) at a greater value of $X$. The same, of course, applies to additional care exercised by the victim (Y). 
also affects the allocation of care between activity and caution levels. How the parties will choose between activity and caution forms of care over time depends fundamentally on the relative benefits of each kind of care. For older products, the manufacturer is able to adjust its total care input only by altering its caution level; the manufacturer's activity level-the number of products produced in past years-is unalterable. ${ }^{36}$

In contrast, consumers are able to alter caution and activity levels in response to the increased risk from older products. A consumer can both exercise greater caution when using an older product, and use it less frequently. Since the consumer's optimal care input also increases as products age, that increased input may be expressed as an increase in the caution level, a decrease in the activity level, or some combination of the two.

This difference between the relative costs of care to manufacturers and consumers suggests that a two-tier standard of liability would best approximate the efficient legal rule. For new products, a rule of strict liability with a defense of contributory negligence gives manufacturers an incentive to adjust their activity to the socially optimal levels. It also gives both manufacturers and consumers an incentive to optimize their caution levels. As the product ages and deteriorates, however, the liability rule must ensure that manufacturers and consumers exercise greater amounts of care and must also provide incentives for consumers to alter their activity levels. Because consumers can most easily reduce their activity levels as the product becomes older and more dangerous, they should bear the cost of most accidents from worn products. Manufacturers should be liable for such accidents only when they have been negligent and the consumer exercised due care in using the product.

Of course, no single liability rule will minimize social cost for all product accidents. And the effectiveness of a split-liability rule will depend ultimately on some estimate of the proper time for the

${ }^{36}$ Because manufacturers cannot easily keep contact with their products after sale, changes in their caution level may be limited to disseminating information about known defects or about proper care and maintenance. For unpredictable and non-uniform defects, however, even these measures would not help to prevent accidents.

The recall of a product might be considered a change in the activity level of a manufacturer, rather than a change in its caution level, since recall takes a product out of the consumer's hands altogether. This is incorrect for two reasons. First, many recalls are not permanent; the product is repaired and returned to the consumer. Second, recalls are not completely efficacious; the consumer must decide whether to return the product. Since the ultimate control of the product rests with the consumer, a recall is more strictly analogous to a warning-albeit a much louder and more forceful one. 
switch from strict liability to negligence. ${ }^{37}$ The strict liability period might be a fixed period of time, such as five or ten years, ${ }^{38}$ or it might be defined by a product-specific "useful sale life" limitation. ${ }^{39}$

\section{The Model and Reality}

The conclusions derived from the time-dependent model are to a large degree already reflected in current products liability law. Section 402A of the Restatement (Second) of Torts has been applied so as to embody the model's recommendation that the legal standard shift from a rule of strict liability with a defense of contributory negligence to a rule of negligence as the product ages. Furthermore, the argument for such a split-liability rule is not undermined by the model's assumptions regarding administrative costs, although the exact nature of the optimal shift will depend upon an accurate assessment of the "real" costs of enforcing different liability rules. However, given the uncertainty over administrative costs which now exists, the current tort regime can be defended as approaching an efficient system of products liability.

\section{A. Section 402A and the Model}

By its terms, section $402 \mathrm{~A}$ does not enact a split-liability rule, but courts have applied it so as to achieve the same effect. There are two principal differences between the literal terms of section $402 \mathrm{~A}$ and the approach suggested by the time-dependent model. First, section $402 \mathrm{~A}$ enacts something less than pure strict liability for product-related accidents. ${ }^{40}$ Pure strict liability would hold a manufacturer liable upon proof that its product caused injury; section $402 \mathrm{~A}$ requires proof of both causation and defect. ${ }^{41}$ This addi-

${ }^{37}$ Clearly, the relative importance of the care inputs of the manufacturer and consumer cannot be expressed as a discrete function. Rather, the function that maps the optimal mix of these care inputs over time will be continuous. A shift in liability rules, however, must be discontinuous. There is no practical way to construct a continuously shifting liability rule that tracks the continuously shifting function. Hence, the split-liability standard suggested here is not optimal; yet it remains a significant improvement over either of the uniform standard liability rules that do not take into account the shift in the relative importance of the care inputs over the lifetime of the product.

${ }^{38}$ Indeed, one study shows that approximately $96 \%$ of all product injuries occur within six years of purchase. The Devils in the Products Liabilities Laws, Bus. Wk., Feb. 12, 1979, at 75 .

${ }^{39}$ See infra note 57.

10 See supra text accompanying note 8 .

41 For a discussion of the meaning of defect in section 402A of the Restatement, see Traynor, The Ways and Meanings of Defective Products and Strict Liability, 32 TENn. L. 
tional burden on plaintiffs may exonerate manufacturers in some situations where the model's approach would not. Second, unlike the model's approach, section 402A does not explicitly apply a negligence rule to wear-related accidents.

In practice, however, these differences tend to be minor. Despite the express language of section $402 \mathrm{~A}$, courts typically do not require proof of defect in accidents caused by new products; in most cases, a defect in the original product is presumed and only causation must be shown. ${ }^{42}$ And for older products, the courts do not consider product wear to be a "defect" within the meaning of section $402 \mathrm{~A} .{ }^{43}$ Injured parties may recover for injuries caused by product wear only if they show that the manufacturer was negligent. In effect, then, the Restatement approach closely resembles a split-liability rule: new product accidents are governed by an almost pure strict liability rule; old product accidents are governed by a negligence rule.

\section{B. The Problem of Administrative Costs}

The fundamental insight of the economic model of tort law is its identification of the need for a shift in the liability rule over time. Such a shift would help to minimize the social cost of accidents by giving consumers incentives to limit their use of and be more careful with older, more dangerous products. There are two ways to provide the necessary incentives: a shift to a negligence rule or a shift to a rule of no liability. In a world without administrative costs, the model predicts that the optimal shift would be to a negligence rule.

But the model's failure to account for the administrative costs of enforcing the various possible standards of tort liability is perhaps its most dissatisfying feature. The model assumes that the administrative costs of all liability rules are equal. ${ }^{44}$ Yet it is obvious that different liability rules do generate different administra-

\footnotetext{
REv. 363 (1965).

42 See, e.g., Holloway v. General Motors Corp., 403 Mich. 614, 624-26, 271 N.W.2d 777, 782-83 (1978); Lee v. Crookston Coca-Cola Bottling Co., 290 Minn. 321, 330-33, 188 N.W.2d 426, 432-34 (1971); Henningsen v. Bloomfield Motors, Inc., 32 N.J. 358, 409-412, 161 A.2d 69, 97-99 (1960); see also Prosser \& KeETON, supra note 1, § 99, at 696-97; Schwartz, supra note 13, at 828-36 (discussing the "malfunction theory" whereby original defect is presumed if the injury occurs shortly after purchase); cf. Kimbrell v. Zenith Radio Corp., 555 P.2d 590 (Okla. 1976) (the fact that a television purchased in 1965 caught fire in 1973 was not enough to establish original defect).

${ }^{43}$ See cases cited supra note 14.

44 See supra note 18.
} 
tive costs. Thus, two questions must be addressed. Does the possibility of higher administrative costs under a split-liability rule undermine the model's rejection of a uniform strict liability rule? Does the probability of lower administrative costs under a regime containing a shift from strict liability to a no-liability rule undermine the model's support for a shift from strict liability to negligence?

1. Administrative Costs Under the Split-Liability Rule. A negligence rule might be thought more costly to enforce than a rule of strict liability with a defense of contributory negligence. ${ }^{45}$ The latter rule eliminates the potentially complex inquiry into whether the manufacturer was negligent and replaces this inquiry with a cleaner and simpler presumption of liability. Although the defense of contributory negligence may require litigation of a similarly complex issue, the inquiry into possible negligence by the plaintiff (the consumer) will usually be less protracted than the inquiry into possible negligence by the defendant (the manufacturer). If so, then a split-liability rule could be somewhat more costly to administer than a uniform strict liability rule with a defense of contributory negligence.

The problem with this criticism of the split-liability rule is that it rests almost entirely on unproven assertions. Although it is firmly established that the strict liability rule in products actions has "substantially eased the plaintiff's burden of proof,"46 this indicates only that consumers are more likely to win cases, not that the cases are any cheaper to litigate. Both sides still must present evidence on a number of potentially tricky issues in the plaintiff's case and must litigate any defenses asserted by the manufacturer. ${ }^{47}$ Even if a strict liability rule does narrow the issues in products liability cases, the high stakes often involved in personal-injury cases may lead the parties to concentrate just as many resources in their struggles over the issues that remain. ${ }^{48}$

15 See Richard Posner, Economic Analysis of Law $\S 6.11$, at 142 , 21.5 , at $441-42$ (2d ed. 1977).

${ }^{4}$ Prosser \& KeEton, supra note $1, \S 103$, at 714.

${ }^{17}$ See supra note 7 (listing the elements of plaintiff's claim); see also Prosser \& KEETON, supra note $1, \S 102$ (discussing manufacturer defenses).

is For example, in a products-liability action under a negligence rule a party who could afford expert witnesses might choose to introduce one expert on the issue of negligence and another on causation. Even assuming that a rule of strict liability would obviate the need for proof on the negligence issue, if the stakes were high enough the same party might choose instead to introduce two witnesses on causation. In wrongful death actions, regardless of the cause of action, the stakes can be quite high. See, e.g., Southern Pac. Transp. Co. v. Lueck, 111 Ariz. 560, 572-73, 535 P.2d 599, 611-12 (1975) (upholding a jury verdict of $\$ 2,000,000$ in 
Moreover, one could see the concept of administrative costs as comprising two elements: information costs, which are generated by enforcing the liability rule in a single case, and claims costs, which are generated by the number of cases brought under the liability rule. ${ }^{49}$ While the above discussion has called into question the common assumption that a negligence rule imposes higher information costs than a strict liability rule, it seems clear that a negligence rule leads to lower claims costs. Because "the elimination of the necessity of proving negligence has greatly improved a claimant's chances for recovery in a particular case,"50 a strict liability rule encourages a greater number of products actions, with correspondingly greater administrative costs. This combination of an uncertain effect on information costs and a clear decrease in claims costs under a negligence rule suggests that the claim of higher administrative costs under a negligence rule is not only speculative, but may well be incorrect.

Furthermore, even if a negligence rule-hence a split-liability rule-imposes greater administrative costs than a strict liability rule, it would be extremely difficult to formulate even a rough assessment of the difference in costs under the two rules. Thus, in the absence of accurate information it is unclear how much significance should be attached to the problem of administrative costs in this context. Given the model's insights into the socially optimal allocation of care over time between the manufacturer and the consumer of a product, it seems unwise to dismiss its support for a split-liability rule without more persuasive evidence about the costs of enforcing alternative rules.

2. Time Limits on Manufacturer Liability. A second potential criticism of the time-dependent model also stems from the model's failure to take administrative costs into account. Recognizing the need for a shift in the liability rule over time, this criticism argues that rather than adopting a shift from strict liability to negligence, it would be more efficient to shift to a rule of no liability. It is certainly true that any liability rule-whether strict liability

compensatory damages and $\$ 1,080,000$ in punitive damages for death of a high school graduate whose income had never exceeded $\$ 6,000$ per year).

19 This terminology is adapted from Landes \& Posner, supra note 15 , at $874-75$, where essentially the same point is presented and explained in a slightly different manner. Although Landes and Posner discuss administrative costs in this passage, they did not incorporate these costs into their economic model. See id. at 869. See generally R. PosNER, supra note $45, \S 21.5$, at $441-42$ (the outcome of the balance between these two elements is uncertain).

so Prosser \& Keeton, supra note 1, \$ 99, at 696. 
or negligence-becomes more costly and difficult to enforce over time. ${ }^{51}$ The passage of time magnifies uncertainty and evidentiary problems. At some point in time the difficulties become large enough to justify a bright-line rule: after a certain period, manufacturers should never be subject to liability. This suggests that the shift in manufacturer liability over time might be achieved more simply through statutes of repose superimposed on a single substantive rule governing products liability. ${ }^{52}$

This recommendation makes intuitive sense; administrative costs must be lower under a shift to a no-liability rule than under a split-liability rule. On the other hand, the cost of miscalculating the timing of the shift in liability rules is greater under a shift to a no-liability rule than under a split-liability rule. If liability is cut off too soon, consumers will be encouraged to retire products too early, and manufacturers will not adjust their caution and activity inputs to socially optimal levels. Thus, the choice between statutes of repose and the split-liability rule is also subject to uncertainties about the proper significance of administrative costs.

This uncertainty is evidenced by the fact that in dealing with the possibility of a time limitation on liability for wear-related accidents, legislatures and courts have widely disagreed about the scope of the administrative cost problem. Indeed, decisionmakers have adopted two diametrically opposed positions. On the one hand, it is plausible to assume that the costs of enforcement will, at some point, be sufficiently large to justify an absolute cutoff in the liability of the manufacturer. Some state legislatures have enacted limiting statutes that implicitly take this position. These statutes of repose make some period of prolonged use, generally five to twelve years, ${ }^{53}$ conclusive against a finding of defect. ${ }^{54}$ Also,

${ }^{51}$ This problem shows up in the traditional justifications for statutes of limitations. See, e.g., Schwartz v. Heyden Chem. Corp., 12 N.Y.2d 212, 219, 188 N.E.2d 142, 146, 237 N.Y.S.2d 714, 718 (1963) ("perhaps the possibilities of feigned cases against unprepared defendants and the difficulties of proof in meritorious cases led to a decision that society is best served by complete repose, even at the sacrifice of a few unfortunate cases").

${ }^{32}$ See Epstein, The Temporal Dimension in Tort Law, 53 U. CHI. L. Rev. (forthcoming).

${ }^{53}$ See Comment, Limiting Liability: Products Liability and a Statute of Repose, 32 BAYLOR L. REv. 137, 144 n.67 (1980).

st The considerations behind this legislative action differ somewhat from those which underlie the judicial rule that prolonged safe use conclusively demonstrates non-negligence. The judicial rule, see Solomon v. White Motor Co., 153 F. Supp. 917 (W.D. Pa. 1957); cf. Schindley v. Allen-Sherman-Hoff Co., 157 F.2d 102 (6th Cir. 1946), is based on concern for accuracy in an individual case and on the idea that prolonged safe use disproves the negligence of the manufacturer. Statutes of repose are based more clearly on ex ante considerations of certainty and minimization of administrative costs. Thus, under a statute of repose 
they usually provide that an action must be brought within a maximum limitation period which runs from the date of manufacture or sale. ${ }^{55}$ Once that period has elapsed, an action is completely barred regardless of whether it is based on strict liability or negligence unless an express warranty provides otherwise. ${ }^{56}$ A manufacturer can insulate itself from liability by establishing that the product has survived prolonged use. ${ }^{57}$

the action is barred if brought after the statutory time limit, even if the accident happened within the statutory limit or if other related actions were brought in a timely manner. The judicial rule relies on the passage of time to prove that the product was not defective; the statutes bar recovery even if it was. Nonetheless, the two rules have virtually the same effect; they absolutely limit manufacturer liability for older products.

Of course, noneconomic considerations will also affect legislative decisions to adopt or reject statutes of repose. For example, legislatures might seek to protect local manufacturers from liability in order to attract new production to the state. On the other hand, the use of a statute of repose as a protectionist measure may be politically unacceptable to the populace because it denies state citizens access to the judicial process.

ss See, e.g., ConN. GEN. STAT. \& 52-577a (1979) (ten years from date manufacturer last parted with possession or control of product); N.C. Gen STAT. § 1-50(6) (Supp. 1979) (six years from the date of sale). For a comprehensive listing of state statutes of repose, see McGovern, The Variety, Policy and Constitutionality of Product Liability Statutes of Repose, 30 Am. U.L. Rev. 579, 580 n.3 (1981); Comment, supra note 53, at 144 n.67.

${ }^{8 B}$ In the absence of a statute of repose, courts may apply a negligence statute of limitations to product liability actions. See, e.g., Victorson v. Bock Laundry Mach. Co., 37 N.Y.2d 395,335 N.E.2d 275, 373 N.Y.S.2d 39 (1975). Under such a statute of limitations, the period does not begin to run until either the injury occurs or, in some instances, is discovered. As a result, manufacturers remain open to potential liability no matter how much time has passed since the manufacture and sale of a product.

${ }^{57}$ Some statutes fix a uniform time period for all products. For instance, the Uniform Product Liability Act sets a date of ten years:

(1) Generally. In claims that involve harm caused more than ten (10) years after time of delivery, a presumption arises that the harm was caused after the useful safe life had expired. This presumption may only be rebutted by clear and convincing evidence.

(2) Limitations on Statute of Repose. (a) If a product seller expressly warrants that its product can be utilized safely for a period longer than ten (10) years, the period of repose, after which the presumption created in subsection (B)(1) arises, shall be extended according to that warranty or promise.

UNIF. Product Liability Act § 110(B) (1977), reprinted in 44 Fed. Reg. 62,732 (1977). Others employ what is called a useful safe life limitation which varies from product to product, an example of which is also provided in the uniform act:

(1) Except as provided in Subsection (A)(2), a product seller shall not be subject to liability to a claimant for harm under this Act if the product seller proves by a preponderance of the evidence that the harm was caused after the product's "useful safe life" had expired.

"Useful safe life" begins at the time of delivery of the product and extends for the time during which the product would normally be likely to perform or be stored in a safe manner....

(2) A product seller may be subject to liability for harm caused by a product used beyond its useful safe life to the extent that the product seller expressly warranted the product for a longer period. 
On the other hand, the exact opposite assumption is also plausible, and many courts appear to have adopted it: although the difficulties and costs of enforcement increase with time, over the relevant life of most products they are insignificant compared to the costs of retiring the product prematurely. This view has led courts to conclude that the safe use of a product for a specified period of time can never constitute conclusive proof that the product was not defective. ${ }^{58}$ They have determined, in effect, that no period of accident-free use can absolutely bar recovery from the manufacturer. Instead, they consider the passage of time to be just one factor in determining liability. ${ }^{59} \mathrm{In}$ this view, the administrative costs of litigation are never too great to preclude a suit.

One further point deserves note. In many states where statutes of repose have been adopted to govern products liability actions, the courts have struck them down as repugnant to their state constitutions. ${ }^{60}$ Although the grounds of these decisions range far beyond the considerations that are the focus of the economic model, ${ }^{61}$

Unif. Product Liability Act $\$ 110(\mathrm{~A})$ (1977), reprinted in 44 Fed. Reg. 62,732 (1977).

${ }^{58}$ See, e.g., Holloway v. J.B. Systems, 609 F.2d 1069, 1074 (3d Cir. 1979) (under section 402A of the Restatement, prolonged safe use of a product does not conclusively prove the absence of defect). This point was often made under a negligence rule as well. See, e.g., Pryor v. Lee C. Moore Corp., 262 F.2d 673, 675 (10th Cir. 1958) ("The proposition that prolonged safe use bars any inference of negligent manufacture has not gained wide acceptance in the application of the MacPherson doctrine."), cert. denied, 360 U.S. 902 (1959); International Derrick \& Equip. Co. v. Croix, 241 F.2d 216, 221 (5th Cir.) (prolonged safe use of "seven years does not, per se, relieve a . . . manufacturer from liability for injuries caused by a defective [product]"), cert. denied, 354 U.S. 910 (1957). But see, e.g., Schindley v. Allen-Sherman-Hoff Co., 157 F.2d 102 (6th Cir. 1946) (manufacturer who made 12,000pound gate used in power plant not liable when gate fell upon plaintiff after gate had been used safely for three years); Solomon v. White Motor Co., 153 F. Supp. 917 (W.D. Pa. 1957) (manufacturer of truck not liable when truck had functioned safely for five years and between 200,000 and 400,000 miles).

so See Tucker v. Unit Crane \& Shovel Corp., 256 Or. 318, 320, 473 P.2d 862, 862-63 (1970) ("The state of the present law is with near unanimity, that prolonged use of a manufactured article is but one factor . . . in the determination of whether a defect in the product made it unsafe for its intended use."); Kuisis v. Baldwin-Lima-Hamilton Corp., $457 \mathrm{~Pa}$. $321,336,319$ A.2d 914, 923 (1974) (" "prolonged use of a manufactured article is but one factor, albeit an important one, in the determination of the factual issue . . . whether [a defect] caused the harm" ") (quoting Pryor v. Lee C. Moore Corp., 262 F.2d 673, 675 (10th Cir. 1958), cert. denied, 360 U.S. 902 (1959)).

${ }^{60}$ See McGovern, supra note 55, at 581. In 1981, at the time of the McGovern survey, 29 states had considered the issue and nine had found the statutes of repose unconstitutional. Id. Since that time, more state courts have invalidated such statutes. See, e.g., Berry v. Beech Aircraft Corp., No. 17,694 (Utah Dec. 31, 1985), summarized in 54 U.S.L.W. 2373 (1986).

61 Several state courts have determined that statutes of repose violate their constitutions because they deprive a plaintiff of his cause of action before the wrong to him may reasonably be discovered. See, e.g., Lankford v. Sullivan, Long \& Haggarty, 416 So. 2d 996 
the decisions themselves bear strongly on the conclusions that can be drawn from the model. In particular, the presence of such constitutional problems narrows the impact of the administrative costs problem. Because the model shows the desirability of some shift in the standard of manufacturer liability over time, the adoption of the split-liability rule may be the only constitutional way to minimize the social cost of accidents caused by defective products.

These wide disagreements underscore the importance to the model of developing more precise assessments of the administrative costs imposed by tort law rules. Nevertheless, the time-dependent model offers two important lessons. First, it demonstrates the need for a shift over time in the standard of liability applied to manufacturers for accidents involving their products, in order to provide consumers with incentives to retire older, more dangerous products. Second, it suggests that the socially optimal allocation of care between manufacturers and consumers supports a shift over time from a strict liability rule to a negligence rule. Thus, in the absence of more accurate information on the administrative costs imposed by various liability rules, the time-dependent model offers support for the current practice of applying a de facto split-liability rule to accidents caused by product wear.

\section{CoNCLUSION}

In order to select an appropriate standard of manufacturer liability, it is necessary to isolate the factors that distinguish productrelated accidents from accidents generally. One central distinction concerns the effects of the passage of time: product-related accidents become more likely as products age. Because of this fact, the mix of conduct by manufacturers and consumers that minimizes the social cost of accidents caused by new products will not minimize the social cost of accidents involving old products. Recognizing that the standard of liability must shift with the passage of time, this comment has argued that a split-liability rule-strict liability for newer products and negligence-based liability for older

(Ala. 1982) (due process guarantees access to court for all wrongs); Battilla v. Allis Chalmer Mfg. Co., 392 So. $2 d 874$ (Fla. 1980) (constitution explicitly guarantees access to courts); Heath v. Sears, Roebuck \& Co., 123 N.H. 512, 464 A.2d 288 (1983) (limitation of action not substantially related to legitimate legislative objective); Daugane v. Baltic Coop. Bldg. Supply Ass'n, 349 N.W.2d 419 (S.D. 1984) (statute of repose repugnant to constitutional guarantee of open courts). But see, e.g., Chestwood Volunteer Fire Co. v. Lamberton Constr. Co., 489 A.2d 413 (Del. 1985) (holding statute of repose constitutional); Fujoka v. Kam, $55 \mathrm{Ha}-$ waii 7, 514 P.2d 568 (1973) (same); Dauge v. Piper Aircraft Corp., 418 N.E.2d 207 (Ind. 1981) (same). See generally McGovern, supra note 55, at 600-20 (discussing the cases). 
ones-will best control manufacturer and consumer conduct. More than other liability rules, this split-liability rule controls the number of goods produced by ensuring that product prices substantially reflect the costs of accidents, and provides incentives for consumers to retire goods when their useful life is completed.

Peter V. Letsou 